\title{
The Use of The Semanding Tuban Limestone as A Partial Replacement of Coarse Aggregate in Concrete Mixes
}

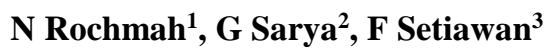 \\ \{nurulita889@gmail.com ${ }^{1}$ \} \\ ${ }^{1,2,3}$ Civil Engineering,Universitas 17 Agustus 1945 Surabaya, Indonesia
}

\begin{abstract}
Concrete is the most widely used material in the world. Expensive construction can be caused by the increasing cost of concrete. In recent years, concrete production has increased which means consumption of coarse aggregate also increased. Natural coarse aggregate is gravel. Due to the growth in the construction industry, the demand for gravel is increasing rapidly, therefore gravel is expensive. In Semanding Tuban, there is limestone which is greater available than gravel in order to reduce concrete cost. In this case there is a need to study the concrete with limestone from Semanding Tuban as coarse aggregate in order to get better understanding of limestone in concrete mixes. The aim of this research is to investigate the compressive strength of the concrete, in which limestone from Semanding Tuban was used as coarse aggregate is partially or completely replaced. The coarse aggregate was replaced with $0 \%$, $25 \%, 50 \%, 75 \%, 100 \%$ by limestone from Semanding Tuban, respectively. The compressive strengths of concrete specimens for respective mix proportions were tested at 14 and 28 days of water curing. In addition the source of aggregate properties was considered in this research: Los Angeles abrasion, absorption and specific gravity for coarse aggregates and fine aggregate. The result of the compressive strength concrete of limestone from Semanding Tuban as addition showed that increased by $0 \%$ to $50 \%$, but it decreased to $50 \%$ to $100 \%$.
\end{abstract}

Keywords: Concrete, Coarse Aggregate, Limestone, Compressive Strength

\section{Introduction}

Concrete is the widely construction material used in building structures[1]. Concrete is the result of mixing of cement, water, fine aggregate and coarse aggregate. In this era the use of concrete is increasing[2], because the concrete-making material is easy to obtain and it has a large compressive strength, the concrete is easy to form in accordance with desires, maintenance costs are small and more resistant to various weather.

This day, concrete production is getting increase. In the need for concrete manufacturing materials has caused a lot of aggregate mining as one of the large concrete mixture materials which has resulted in a reduction in the number of natural sources available for making concrete. 
Now the source of natural gravel is now depleting its supply. Then to be able to meet the availability of material that is depleting, it need to use alternative materials to substitute aggregate concrete mixtures with other materials that have not been widely utilized, and it must meet the specified standards.

Tuban Regency is located in East Java province with wide area 1,904.70 km2 and the length of the beach reaches $65 \mathrm{~km}$. Tuban district is known as the city of a thousand caves located in limestone mountains. Part of the Tuban area is a limestone hill, where there are many quarries which are dominated by quarries which are scattered in several locations in the Tuban Regency. One of that area is Semanding.

With the existing background. Researchers want to use Semanding Tuban limestone to be used as a substitute for coarse aggregate in concrete mixtures. The aim of this research is to get better understanding the compressive strength of the concrete, in which limestone from Semanding Tuban was used as coarse aggregate is partially or completely replaced.

\section{Method}

\section{a. Objective}

The aim of this research is to get better understanding the compressive strength of the concrete, in which limestone from Semanding Tuban was used as coarse aggregate is partially or completely replaced.

\section{b. Material Used in Concrete}

\section{Cement}

Cement is a mixture that is chemically active after contact with water. Aggregate does not play an important role in the chemical reaction, but serves as a mineral filler that can prevent changes in the volume of concrete after stirring is complete and improve the durability of the concrete produced. The cement can be divided into two groups, namely hydraulic cement and non-cement hydraulic.

Ordinary Portland cement type I was used throughout the experimentation. The ASTM has designed five types of portland cement, designated types I-V. Cement type I for general construction [3].

\section{Coarse Aggregate}

According to SNI 1970-2008, coarse aggregates are gravel as a result of natural disintegration of rock or crushed stone obtained from the stone- breaking industry and have a grain size of between $4.75 \mathrm{~mm}$ (No.4) to $40 \mathrm{~mm}$ (No. 11/2 inches). Based on ASTM C33 Rough aggregates consist of gravel or crushed stone with grain particles larger than 5 $\mathrm{mm}$ or between $9.5 \mathrm{~mm}$ and $37.5 \mathrm{~mm}$. Aggregates used in concrete mixtures are usually smaller than $40 \mathrm{~mm}$.

This study used two kinds of coarse aggregates, there is limestone from Semanding, Tuban, and gravel with specific gravities 2,13 and 2,78 respectively were used as given in table 2 . 


\section{Fine Aggregate}

Fine aggregates are rocks whose grain size is smaller than 4.75 (ASTM standard) and $4.80 \mathrm{~mm}$ (British Standard). The fine aggregate has an aggregate with a maximum grain size of $4.75 \mathrm{~mm}$ (SNI 02-6820-2002). This fine aggregate obtained from the disintegration (destruction) of natural rock (natural sand) or can also solve it depends on the conditions of the formation of the occurrence.

This study used one fine aggregate with specific gravities 2,78 which is presented in table 1. The method that used to test specific gravities is ASTM C-128 [4].

\section{Water}

In concrete mixtures, water is one of the most important factors, because water can react with cement, which will be an aggregate binder paste. Water also affects the strongly forced concrete, because excess water will cause a decrease in the strength of the concrete. In addition, excess water will result in concrete being bleeding.

\section{Limestone}

Limestone $(\mathrm{CaCO} 3)$ is a sedimentary rock composed of mineral calcite (calcium carbonate). The main source of calcite is marine organism. These organisms remove the shell out into the water and deposited on the ocean floor as pelagic ooze.

Tabel 1. The Properties of Fine Aggregate

\begin{tabular}{|l|c|}
\hline \multicolumn{2}{|c|}{ The Properties of Fine Aggregate } \\
\hline Specific gravity & 2,78 \\
\hline Absorption (\%) & 1,21 \\
\hline Humidity (\%) & 9,65 \\
\hline
\end{tabular}

Tabel 2. The Properties of Coarse Aggregate

\begin{tabular}{|c|c|c|}
\hline The Properties of & Limestone & Gravel \\
\hline Specific gravity & 2 , & 2 \\
\hline Absorption (\%) & 7 & 1 \\
\hline Humidity (\%) & 10,38 & 2 \\
\hline Abration (\%) & 2 & 34,4 \\
\hline
\end{tabular}




\section{c. Experimental Procedure}

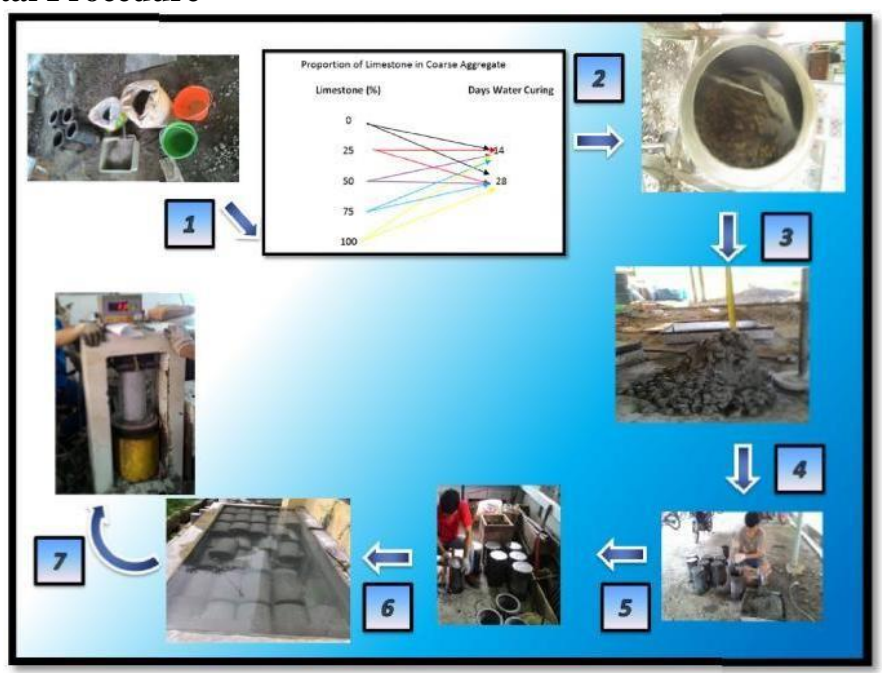

Figure 1 - Experimental Procedure

Five mixes were prepared; There are $0 \%$ limestone (as a control), 25\% limestone, $50 \%$ limestone, $75 \%$ limestone, and $100 \%$ limestone for each set of mix design. The composition of each aggregate was $70 \%$ coarse aggregate with a maximum $40 \mathrm{~mm}$ size and $30 \%$ fine aggregate which was included in zone 3 . The water cured concrete specimens were tested at the age of 14 , 28 days. The specimens were tested in compression testing machine which is presented in figure 1. The Properties of an aggregate such as specific gravity, absorption [5] and abrasion [6] are tested which are showed in table 1 and 2. Workability is tested by performing slump cone test for each set of mix as shown in table 3. Compressive strength was tested on $150 \mathrm{~mm}$ diameter and $300 \mathrm{~mm}$ height cylinder. Three Cylinders were tested for each mix which means this research totally 30 cylinders. The experimental procedure is shown in figure 1 .

Tabel 3. Slump Result Test for the Mix Design

\begin{tabular}{|c|c|}
\hline \multicolumn{2}{|c|}{ Slump height for the mix design } \\
\hline Limestone content & M20mix design \\
\hline $0 \%$ & $90 \mathrm{~mm}$ \\
\hline $25 \%$ & $82 \mathrm{~mm}$ \\
\hline $50 \%$ & $76 \mathrm{~mm}$ \\
\hline $75 \%$ & $70 \mathrm{~mm}$ \\
\hline $100 \%$ & $67 \mathrm{~mm}$ \\
\hline
\end{tabular}




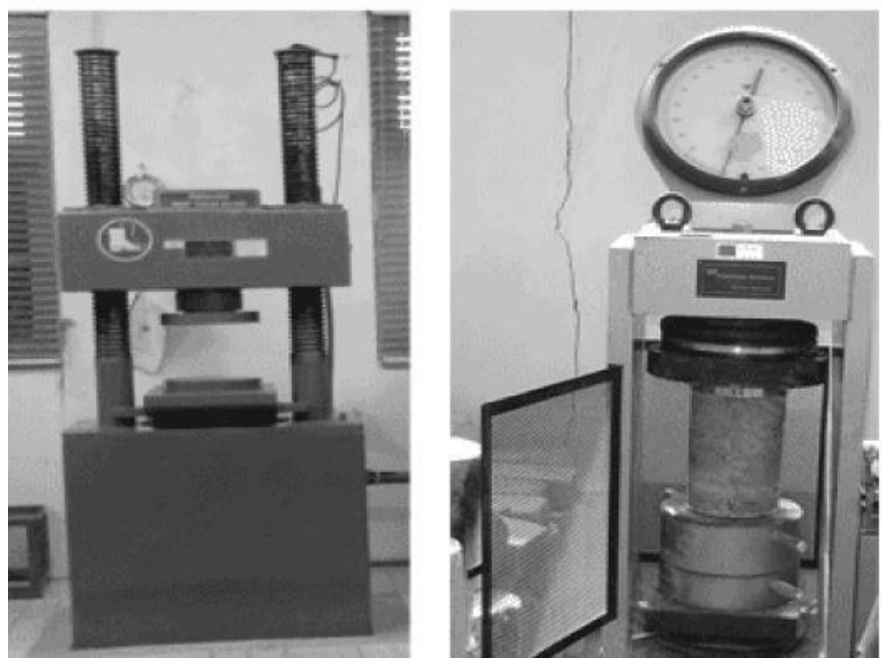

Figure 2 - Compression Testing Machine

\section{Result and Discussion}

Results that are obtained for each laboratory test are tabulated as shown below. Also graph is drawn for the results to compare each mix.

Tabel 4. Compressive Strength

\begin{tabular}{|c|c|c|}
\hline Mix & Different Mixes & Compressive Strength $\left(\mathrm{Kg} / \mathrm{cm}^{2}\right)$ \\
\hline 1 & $0 \%$ Limestone & 97,44 \\
\hline 2 & 25\% Limestone & 99,94 \\
\hline 3 & $50 \%$ Limestone & 113,11 \\
\hline 4 & $75 \%$ Limestone & 90,37 \\
\hline 5 & 100\% Limestone & 86,85 \\
\hline
\end{tabular}

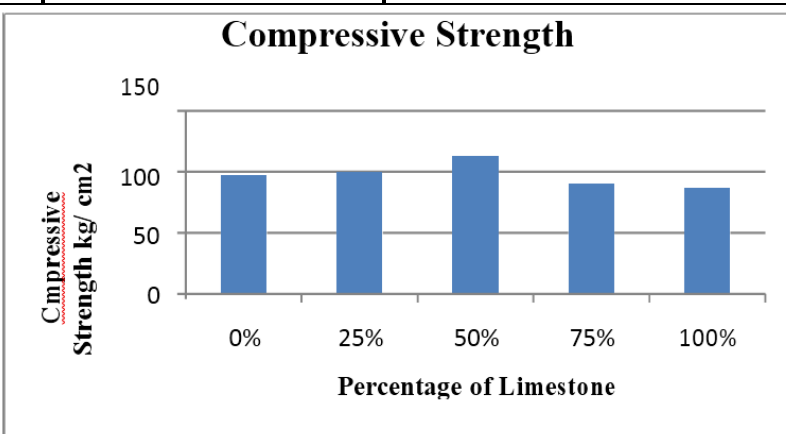

Figure 3- Compressive Strength Test Results for C20 Concrete in $\mathrm{Kg} / \mathrm{cm}^{2}$ 


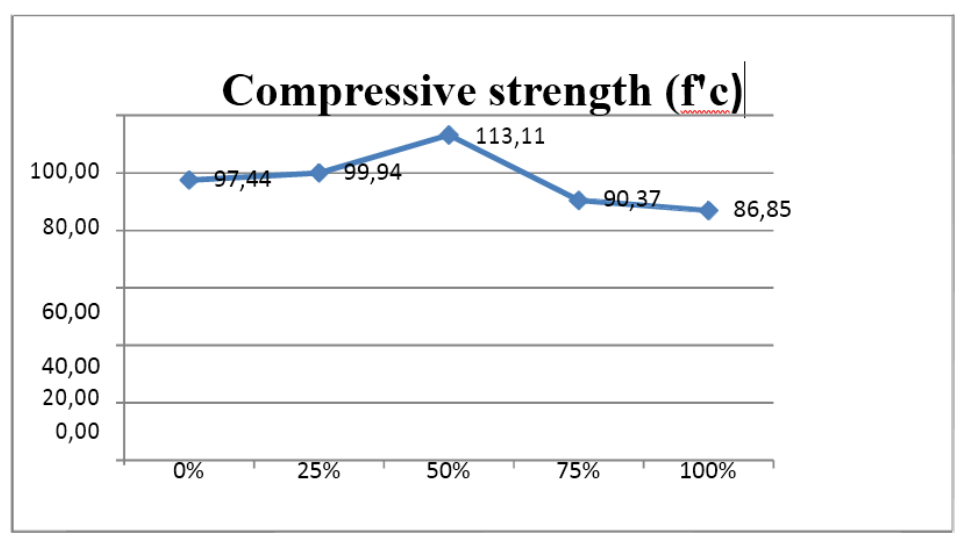

Figure 4 - Compressive Strength Test Results for M20 Concrete in $\mathrm{Kg} / \mathrm{cm}^{2}$

\section{Conclusion}

The result of this investigation showed that increase of the fraction of Limestone from Semanding, Tuban as addition in concrete addition showed that increased at $0 \%$ to $50 \%$, but it decreased at $50 \%$ to $100 \%$. Another result is the economic design of concrete can be done by using $50 \%$ Limestone.

\section{Acknowledgement}

This work was supported in part by the Untag Surabaya.

\section{References}

[1] D. Yeo and R. D. Gabbai, "Sustainable design of reinforced concrete structures through embodied energy optimization," Energy Build., vol. 43, no. 8, pp. 2028-2033, Aug. 2011.

[2] T. Ji, "Preliminary study on the water permeability and microstructure of concrete incorporating nano-SiO2," Cem. Concr. Res., vol. 35, no. 10, pp. 1943-1947, Oct. 2005.

[3] ASTM C 150/C150M-15, "American Society for Testing and Materials. Standard Specification for Portland Cement." ASTM International:, West Conshohocken, PA, USA, 2015.

[4] ASTM C 128, “American Society for Testing and Materials. Standard Specification for Spesific Gravities.” ASTM International, West Conshohocken, PA, USA, 2015.

[5] ASTM C 128-93, "American Society for Testing and Materials. Standard Specification for Absorption.” ASTM International, West Conshohocken, PA, USA, 2015.

[6] ASTM C 566, "American Society for Testing and Materials. Standard Specification for Humidity.” ASTM Internationa, West Conshohocken, PA, USA, 2015. 